\title{
KULTURÁLIS ANTROPOLÓGIA ÉS A KATONA
}

\section{Szerző:}

Harai Dénes (PhD, CSc)

Nemzeti Közszolgálati Egyetem

Szerző e-mail címe:

Harai.Denes@uni-nke.hu

\section{Lektorok:}

Koncz István (PhD, CSc)

Professzorok az Európai Magyarországért

Egyesület

Mező Ferenc (PhD)

Eszterházy Károly Egyetem

...és további két anonim lektor

\begin{abstract}
Absztrakt
A háborúk és a katonák mély hatással vannak a történelemre, ugyanakkor az ezekkel szembeni társadalmi hozzáállás erősen függ a kultúrától. A háborúk, a katonák és a kultúrák közötti kölcsönhatások a civilizációk fejlődésének alapvető részét képezik. Ennek a tanulmánynak a célja a kulturális antropológiával és a katonákkal kapcsolatos tények és jelenségek rendezése, elemzése és értelmezése.
\end{abstract}

Kulcsszavak: kulturális antropológia, katona

Diszciplinák: hadtudomány

\section{Abstract}

CULTURAL ANTHROPOLOGY AND THE SOLDIER

Wars and soldiers have a deep impact on history, but at the same time, the societal attitudes toward these are strongly cultural dependent. The interactions among wars, soldiers, and cultures are an essential part of the development of civilizations. The aim of this study is to organize, analyze and interpret some facts and phenomena about aspects of cultural anthropology and the soldiers.

Keyword: cultural anthropology, soldier

Discipline: military science

Harai Dénes (2019): Kulturális antropológia és a katona. Lélektan és hadviselés - interdiszciplináris folyóirat, I. évf. 2019/1. szám. 43-58. doi: 10.35404/LH.2019.1.43 
A Krisztus-előtti, mondhatnánk, „régitársadalmak" technikáinak, módszereinek és intézményeinek alapformái katonaiak, melyek szerkezetei szerves kapcsolatban maradtak, a változó fizikai és emberi természettel. A jelzett időszakban, a „társadalom" még a hadsereg része volt, mert az ember és közösségeinek élet-, munka-, és küzdelem-módja, annak - gondolati és gyakorlati kombinációi - ösşetapadt állapotban voltak. Az egymást követő integrációikat - L. H. Morgan megfogalmazásában - „napjainkig megmaradt hasonló alakzat-részekből" is le lehet vezetni. A vizsgálat alapelve az ember valóságos élethelyzetei, szülkségletei - Ferenczi Sándor (1873-1933) nyomán, azt mondhatjuk (Ferenczi, 1918) legegyszerübb ténykedési ösztöneinek -, értékeinek, érdekeinek, céljainak, megoldási módszereinek, valamint karaktereinek vizsgálata a gépi hadviselés korszakában, a katona kulturális-antropológiájának szempontjából. B. Malinowski is hangsúlyozza a társadalom fontosabb intézményei, az emberi lények elsődleges (biológiai) szükeségleteivel vannak összhangban, ezért, egy társadalmi tény funkcionális magyarázatának, fel kell tárnia a szóban forgó tény értékét a fennmaradás szempontjából, kimutatva funkcióját, az emberi lények elsődleges szükségleteinek kielégítésében (v.ö.: Nagel, 2005, Malinowski, 1968). A történelem folyamán a szükségletek is változnak. A különböző szemléletekkel ellentétben, a háború önmagában nem müveltség vagy barbárság kérdése, sokkal inkább a mindenkori hatalmipolitikai - gazdasági intézményrendszer működésének függvénye, következménye. A problémát fölvetni, úgy gondolom, hogy a küzdelmi alakzatok közül a háború, - nukleáris korunkban a gépesített háború - kontextusában lehet, mivel ez a végzetdimenzió visszavetül a tartalmakra, a gondolkodási struktúrákra, mozgásformákra, technikai rendszerekre, és viszonyaik ebben ragadhatók meg. A téma önmagában is eposzi. A katona a társadalmi világ természetéhez tartozik, és mint jelenséget, a közgondolkodás a háborús mezőben tapasztalja, de nem lehet csupán a katonai fogalomrendszerrel vizsgálni, mert a folyamatokban személyiségének egésze érintett. E tekintetben mind a fizikai-, mind a szociál-antropológia kapcsolatba hozható a katonával. „Ezért mindenki, aki eldobja a kardot, kard által vész el" - olvashatjuk az evangéliumban (Máté. 26:51-52). „Mostanáig minden egyes kultúra a «transzcendencia» és a «bestiárium» közötti feszültségben élt...A bestiárium azon intézmények együttese, amelyek valamely adott civilizációban az embertelenséget létrehozták és végtelenítik, és az eszme szokások és intézmények által kitermelt emberek konglomerátuma együttesen joggal nevezhető «bestiáriumnak»." - írta Fehér Ferenc (2007). Hozzátehetjük, hogy a latin „bestiarii”- kifejezés, keletkezésekor kitünó harcost jelentett, amelyhez hozzá tehetjük, hogy az élet-halál harcban, - amikor minden gát átszakad - vadállattá válva megmenekül a traumától. Napjainkig őrzik a fogalom jelentését olyan változatok, mint: „bestiális kegyetlenséggel” - ami nem szorul magyarázatra; vagy „átkozott bestia” - 
mondják olyan nőre, aki túljár mindenkinek az eszén, számító, rosszindulatú, és ha szükségesnek látja, bármilyen kegyetlen eszközökkel is eléri célját. E folyamat feltételezi:

a) a társadalom és a hatalom múködésének mechanizmus-szerűségét és e mechanikussággal szembeni alternatívák gyengeségét;

b) hatalom által birtokolt intézmények, tárgyak erős hatását az emberre, egészen a gondolkodás meghatározásáig (szimbólumok, beállítódások);

c) az elhúzódó, összetett válságfolyamatokat;

d) egy-egy újabb, modernebb irányt a történelmi mozgásban, amely elemeinek kombinációja nem érinti, az ismétlődő folyamatok természetét.

A mechanizmusszerű működésmód átható erejét nem szabad leértékelnünk. Az adott időszakokban egymást követik a fordulatok, amelyeknek az elfogadásához és tudati feldolgozásához a társadalmak csoportjainak, rétegeinek jelentősen eltérő érdekei füződnek. A múlt elutasítása, átértékelése érintette a hadseregeket is KeletEurópában.

Az elmúlt két évszázad főbb tendenciáinak egysége négy fogalommal ragadható meg:

a) Technika-technológia, amelynek rendszereiből az ipari társadalom és a gépi hadviselés létrejött (az értelem a technológiákba és a tudományba szublimálódott). Miként az ipari környezetben a gép, az elektronizált-digitalizált géprendszerek teszik ökonomikussá és hatékonnyá a munkát; úgy a fegyver, a fegyverrendszerek teszik ökonomikussá, hatekonnyá, egyben - jelentős mértékben - személytelenné a pusztítást.

b) differenciálódás (bonyolultabb alakzatok, nagyobb tagoltság, élesebb különbségek keletkezése);

c) globalizáció (integrációk halmazai), de ezen halmazok elemei között vannak a korábbi időszakokban létrejöttek is; valamint

d) a relativizálódás-fragmentálódás (értékvesztések, rangsorok átrendeződése, szétszakadások). A jelzett tendenciák felszívták az archaikus alakzatokat, amelyek új jelentésrétegeket vettek fel, és ezek eredetét nem, vagy alig ismerjük fel a globális világ kríziseiben; az energiaforrásokért folyó küzdelmekben; valamint az expedíciós hadseregek, és a terroristák szembenállásában. Napjainkban, a háború jelentései között van olyan változat is, amelyről Eco (2007, 11. o.) így ír: „...a múltban az agresszor elleni igazolható erőszak a fegyverekkel megvívott háború alakját ölthette, ma viszont könnyen lehet, hogy a fegyverekkel megvívott háború olyan formája az erőszaknak, amely nemhogy megfékezné az agreszszort, még használ is neki." 
A katonai kifejezések jelentősen hozzájárultak az ember elvont gondolkodásának, logikájának fejlődéséhez, gondoljunk az olyan fogalmakra, és tényekre, mint: a csapda, csel, becserkészés-bekerités, kiébeztetés, a párbaj; vagy egy másik sikon: a vezér, haditanács, ellenség, idegen, fegyver, katonaköpeny, málhazsák, szabályzat. Kezdetben egy-egy néptörzs egyben hadsereg is volt, mint T. B. Macaulay $(1961,53$. o.) írja: „Egy vadász- és pásztorközösségben minden férfi könnyen és szükségszerűen válik katonává. Rendes hivatása teljes mértékben öszszeegyeztethető a hadiszolgálat követelményeivel. Bármilyen távol fekszik is a hadművelet célja, könnyen viszi magával a létfenntartásához szükséges dolgokat. Az egész nép - hadsereg; az egész esztendő menetelés. Ilyen társadalmi berendezkedés segítette Attilát és Tamerlánt gigantikus hódításaikhoz.” Ebből az időszakból a hadseregben megmaradt napjainkig: a törzs, és a törzsfönök kifejezés. Nem véletlen, hogy a katonai területről terjedtek szét olyan kifejezések, mint: „Ne sirr! Katonadolog”, vagy „katonásan feszes”, vagy ,firet, mint egy katonatiszt”, „, a gyerek katonásdit játszike”, stb. A katonai mező eszłkalálódásának jelentős hatása volt, a vizsgált időszakban a társadalmakra. Mi marad meg a katonából - földrajzilag is értelmezhető tényként (területben) a narratív emlékezetben? - kérdezhetjük. Két jelentős dolog: az elfoglalt vagy visszafoglalt terület, valamint a hírnév. A hadseregek működtetésének olyan végső következményei is vannak, mint a tömeges halál, sebesülések és a báborús trauma. Ferenczi Sándor megfo- galmazásában, a kor (a 20. század) egyik sajátossága volt, hogy az embert valamiképpen úgyis megsemmisítették, s ez mintegy a tudatban megerôsítette az eröszakos halál képretét. A korszak formája az erőszak, valamint: az egyéni és a kollektiv konfrontációja volt.

Antropológiai vonatkozásban utalhatunk az egyéni védelem „ösztönösségére”, mivel védekeznie már akkor kellett - a növények, rovarok, állatok vagy az időjárás ellen -, mielőtt az embernek történelmileg ismert ellenségei lettek volna. Jóllehet, hogy ez a „mielőtt”, akár évezredeket is jelenthetett; nem beszélve arról, hogy azóta is, folyamatosan kell. A ,védelem” ösztönére azonban, az anyaállat viselkedése a legjobb illusztráció, amikor kölykét védi a pusztító veszélyektől, mint $A$. Schopenhauer (1943, 58-59. о.) írja: „....még a legszelídebb állatok is készek ivadékuk érdekében a legegyenlőtlenebb, életre-halálra vitt harcra,...Egy hangyát keresztben kettémetszettek és látták, hogy első fele még bábjait helyezte biztonságba..." A védelem ösztöne, a küzdelmekben évszázadról-évszázadra újabb megerősítéseket kapott, mert alakzatai tízezerszámra ismétlődtek. A mindig új generációk életbe való belenövése (natalitás), ismétlések, utánzások sorozatain keresztül történik. A jelzett ismétlések a jövöre irányuló mozzanatok, amelyek magukba rejtik az eszmélés, és az újraeszmélés szükségességét az egyes embereknél. „Az újjáteremtődés révén állandósult agyunk ugyanaz az agy, amely régmúlt korok barbárjainak és vadjainak a koponyája zárt magába, és 
amelyet az idők folyamán áthatottak, nemesre érleltek mindazok a gondolatok, törekvések és szenvedélyek, amelyek a közbeeső korszakokban foglalkoztatták. Az agy ugyanaz, ami volt, csak a korok tapasztalatai idősebbé és nagyobbá tették" írja L. H. Morgan (1962, 58. o.). A kínai hadviselés törvényeinek jelentős része, az antropológiai jellemzők rendszeres megfigyelésén alapult. Idézzünk néhány példát az elmúlt évezredek hadviselésének tapasztalatából:

„Ha az ellenséges katonák fegyverükre támaszkodnak, akkor éhség gyötri őket. Ha vizet merítvén első dolguk, hogy igyanak belőle, akkor szomjúságtól szenvednek. Ha az ellenség előnyöket pillanthat meg, és mégsem tör előre, akkor kimerült. Ahol a madarak megállapodnak, ott nem lehet ellenség. Ha éjszaka egymást hívogatják az ellenséges katonák, akkor félnek... Ha tisztjeik dühöngenek, akkor fáradtak a katonák. Ha a katonák gabonával etetik a lovaikat, maguk meg csak húst esznek, ha nem akasztják vissza helyükre a boros edényeket és nem is térnek vissza táborukba, akkor végső szorultságukban mindenre készek. Ha a tisztek nagy barátságosan és udvariasan beszélgetnek embereikkel, akkor elveszítették a tömeg bizalmát. Ha minduntalan jutalmakat osztogatnak, akkor nehéz helyzetben vannak. Ha meg gyakran büntetnek, akkor is szorult a helyzetük. Ha eleinte szigorúak, később pedig félnek a katonáiktól, akkor semmit sem értenek a dolgukhoz." (idézi Sun Ce gondolatait Hahn, 1963, 223-224. o.).
A kínai Sun Ce által leírt archaizmusokat, azért hangsúlyoznom, mivel a kutatás során, a külső és belső világok jellemzői, egymásra hatásának dinamikája érdekelt, s e világok kapcsolata, kölcsönhatása igen sokrétű. A háborúban a külső környezet is összeomlik, kaotikussá válik, és a külső instabilitás elindíthat, és gyakran elindít egy belsőt is.

Míg a 19. századot a kibontakozó gépi háborúk klasszicizmusa, a 20. századot már az autoritás, a két világháború, a helyi háborúk százas nagyságrendje, a korlátlan fegyverkezés, az atomfegyverek megjelenése-bevetése, a háborús veszélyek szüntelen rezonanciája jellemezte. A személyiség uniformizálásának, megsemmisítésének óriási méretei voltak a tömeghadseregek időszakában. Míg Julius Caesar hadjáratainak közelítően hárommillió, addig a gépesített háborúknak és forradalmaknak közel háromszázmillió áldozata volt. A 20. „Hadköteles" évszázadunkban, az egyes ütközetek áldozatainak száma is, például a verduni (1916. február-december) elérte az egymilliót; a sztálingrádi (1942. szeptember-1943. január) már elérte a kétmilliót. Akiknek a háborúkat sikerült végig harcolniuk, végig rabolniuk vagy végig kereskedniük - Ferenczi Sándor kifejezésével - azoknak ez volt a „Normalzustandja” (természetes állapota) és tegyük hozzá, még így sem biztos, hogy ők jól érezték magukat benne; azok pedig biztosan nem, akik végig rettegték, operálták, gyógyították, temették, imádkozták.

A közvélemény-kutatásokban általában a félelmet keltő tényezők közül a háború 
az első helyen van, mint a szörnyüségek sűrítménye, fenyegető, rémületkeltő alakzata, az emberi szenvedéstörténet rész̧e. A természet nyelvén halál annyi, mint megsemmisülés - írja Schopenhauer (1943). Egyben ez a lényege a fegyveres harc egyetemes fogalmának. Azaz a háborúnak nem az ószövetségi-zsidó, vagy középkori keresztény fogalmából indulunk ki a modern háborúban sem, hanem ebből, az abszolút tartalomból, a megsemmisitésböl - megsemmisülésből, amely az évezredek folyamán nem változott. A háborúk célját illetően még nem értük el, amiről 1602-ben Campanella (1602/1942) azt írta, hogy a jövőben: „...csak azért kell háborúzni, hogy az embereket jobbá tegyük, s nem azért, hogy megsemmisítsük őket.” C. G. Jung közlései nyomán is megalapozottan feltételezbetjük, hogy a kulturtársadalmak vékony tudatikérge alatt, archaikus tartalmak búródnak.

Módszertanilag hangsúlyozni kell, hogy a kulturális antropológia bizonyos jellemzői alapvetöen megváltoztak, különösen a 20. század végére:

a) a hadvezéreket, hősöket mítosz már nem veszi körül, nem isteni mintaképek, elvesztették apa-lény természetüket is;

b) családjaikban nincsenek (felderítésre váró) dinasztikus hagyományok;

c) nem kapnak olyan jelzőket, mint Attila, akit „metus orbis, flagellum dei”, „,isten ostora"-ként neveztek meg, mint ahogyan erre - áttekintve a Nagy Sándor hagyományt Magyarországon - Borzsák István (1984, 32-
33. o.) utalt: „...Alexandros, akinek győzhetetlensége legalább annyira gazdagította a mitikus Héraklész tiszteletét, mint fordítva, és aki egyrészről örökölte az ókori Kelet legendás hőseitől a hegyek átvágásának, úttalan sziklák járhatóvá tételének, megközelíthetetlen várak elfoglalásának dicsőítését,..." - ami a motorizáció időszakában már nem kultuszépítő faktor, de megmaradt $a$ virtus, vagy egy modernebb kifejezéssel illetve, a vagánysági-index.

d) nagyságrendekkel kisebb irodalmi és képzőművészeti hagyomány ábrázolja őket; legtöbbjük személyi adatlapja, megtalálható a levéltárakban; fényképek, filmek ôrzik alakjukat, ruházatukat; lemezek és hangszalagok hangjukat (Kossuth Lajos hangjáról is készült felvétel). Meg kell jegyezni, hogy a siker, a tekintély mintái jelentősen megváltoztak, és a klasszikusság iránti igény szertefoszlott;

e) a történetírás már nem élhet időbeli átúsztatásokkal; de a katona személyiségekben (is) találhatunk - C. G. Jung kifejezésével - archetipikus, ösi maradványokat. A modern vezérek mítoszát, inkább csak a törzstisztek építik. A fentebb jelzett archaizmusok tekintetében, különösen a hadviselésben maradt meg a szívós kontinuitás, a vizsgált évszázadokban is.

Jelentős hatással van napjaink szélsőséges helyzeteiben a viselkedések értékelésére, hogy fél évezreddel vagyunk a bumanizmus 
és a reneszánsz után, nemzetközi- és emberjogi feltételek között múködnek a hadseregek.

Hozzá tehetjük azonban, hogy a nemzetközi jog általában nem állta, és nem állja útját jelenkorunk helyi háborúinak, fegyveres összecsapásainak sem. A 20. szá-zadban is a háborús szándékok mélyén meghúzódott egy népirtó diszpozíció: gondoljunk...

...a 3 millió halottra a vietnami háború alatt 1967-1973;

...a több, mint 1 millió halottra 1975-79 között Kambodzsában;

...a több, mint 500.000 halottra 1981 ben El Salvadorban;

...a 800-1000 fő közötti halottra 1982ben Libanonban a Sabra és Shatila Palesztin menekülttáborokban;

...a 200.000-500.000 közötti halottra Rwandában;

...Tibetben a 2000 halottra 1989-90 között;

...a Boszniai háború több, mint 200.000 halottjára az 1990-es évek elején;

...az iraki térség 3.000.000 civil áldozatára.

„Ellenség hirére / Vitézekenek sqive / Gyakorta ott felbuzdul; / Söt azonkivül is / Vitéz. próbálni indul; / Holott sebesedik, / Öl, fog, vitéakedik, / Homlokán vér lecsordul." - írta Balassi Bálint „Egy katonaének / In laudem confiniorum: az «Csak búbánat» nótájára" című versében (megtalálható: Bálint, 1924). Ezen a próbálni induláson valódi szabadságot kell érteni, a vitéz nem kerülte, hanem kereste a szembefordulás lehetőségét az ellenséggel, mert csak az összecsapásban lehet megmérettetni - de évszázadokkal később - az ipari hadviselés korában a katona, mint szabad fegyveres vállalkozó alárendelődött a gépezetnek.

A gépesítettség és az egyéni vagánysági index konfliktusa alakul ki, mert a reguláris haderőkben az egyéni kezdeményezést szankcionálják, mivel súlyosan veszélyeztetheti a kollektív cselekvést, vagy egyszerűen az életet. A fegyveres intézmények révén a függés alapélményévé vált az embereknek az elmúlt két évszázadban is. Archaikus elemekkel átszőtt volt már a neveltetése is, különösen a fiúgyermekeknek, gondoljunk a viselkedésbeli eltévelyedés esetén a betörésre, a kemény fegyelem alatt tartásra, a feltétlen - minden körülmények közötti - kötelességteljesítésre és felelősségvállalásra való szorításra. A katona instrumentális léte - fegyverzete és fegyverrendszerei - az ipar működési szabályszerűségeinek függvényeként koncentrálódnak, és új katonai szervezetei struktúrákba, hadrendekbe illeszkednek. A hatalmi akarat „akadályai” (kisebbségek és más csoportok, stb.) csak ettól kezdue váltak a totális megsemmisithetöség mérlegelésének tárgyául. Az ipari korszakkal a természetes- és a mesterséges társadalmak kontrasztja, a haladás és a lemaradás aszimmetriája éleződött, ugyanakkor a hatalmi vágyat nagyságrendekkel felerősítette a műszaki-technikai megismerés, valamint a mérnökök-technikusok csatlakozása a hatalmi célokhoz. A vezető ipari nemzetek (egyre ritkábban) karizmatikus vezetöi, új technikai szinten kerültek közelségébe a történelmi szerep- 
nek, mert háború esetén, a végletekig fokozhatták az erôkifejtést (atombombák, szőnyegbombázások, stb.), ami háborúkban totális pusztításhoz vezetett. Meg kell említeni, hogy a gépesített haderőkben a katona alapélményei (is) elsősorban a technikához kötődnek.

A történetírásról Paul Ricoeur (1991) megfogalmazta, konstrukcióink jelentik a rekonstrukciókat, a logikai valószínűség bizonyossága mellett. Az ,egyszerü” és összetett kulturális, intézményi és emberi tényekből adódóan, a bizonyítás problémája e tények felfogásában, értéktartalmunk, fogalmi alakzataik kidolgozottságában és megértésében, tapasztalatuk, valamint következményeik értelmezésében, megélésében, az ismétlődések hasonlóságának felismerésében van.

Katonai területen a szenvedés realitásánake élménye a következő faktorokból áll össze:

a) elszakadásból (bevonuláskor a családtól, szülőhelytől, megszokott életfeltételektől való elszakadás);

b) elvesztésből (szülők, család, otthon, emlékhelyek, bajtársak, stb.);

c) bombázás - aknarobbanás - emberhalál okozta traumákból;

d) emberi destruktivitásból, megfosztásból (deprivácio), és kifosztásból (háztartások, múzeumok, de - újabb adatok nyomán - katonák kifosztására is gondolnunk kell, stb.);

e) az eröszakos halál intenzív jelenlétéböl (fegyveres harc, fogolytábor, mun- katábor - megsemmisítő tábor, gulag, stb.);

f) emlékezetből; de őrzik az archaizmusokat a katonai léthez tapadó rituálék is, így például: a zászlószentelés, eskü̈tétel, katonatemetés, tábor mise, vagy a feltétel nélkeüli megadás rituáléja, a magasabb parancsnoki szemlék, diszszemlék,stb. Említenünk kell az esetleírások és élettörténetek (katonáknál a szolgálati minősítések) jelentőségét, értelmezését is.

A kultúrában a halál jelenléte, a rideg egoizmust mindig megtöri és visszautalja az embert közösségi életébe. A háborúban szerzett fizikai sérüléssel, csonkulással és halállal, de a puszta rémületkeltéssel, félelemmel a természet szüntelenül betör az emberek tudatába. A lelki kötődések elszakadnak, eloldódnak. A spanyol kultúrában a birtelen halál (bikaviadal), szemben áll szellemiségében, a keresztény kultúra utolsó ítéletével (Apokalipszis), de a háborúkban másodpercenkénti gyakorlattá válik. A harc feszültség-terében megeshett, hogy a katona észre sem veszi, hogy a mellette rohamozó bajtársát halálos lövés érte. $A$ szélsöséges feszültséghelyzetekben mindig jelen vannak az elfojtások, megszállások, elōitéletek és a gyülöletspirálok is. A katonai-mező a sajátos indítékok, érdekek, értékek, célok, konfliktusok, személyi - intézményi-tárgyi szerkezetek, viszonyok sorozataiból, valamint kapcsolataik kombinációiból, differenciáltságából áll. Gondoljunk például a politika - gazdaság - hadsereg; az egyén - hadsereg - társadalom, a hatalom - hadsereg - 
identitás, vagy az animalitás - bumanitás kultúra szerkezeteire. Az erōs nemzetségi érzés kötőszövete - már Attila korában is - a hadsereg volt. Ez vezetett a középkor végére, határozott államkeretben a magyar nemzet kialakulásához. A spinozai módszer meghatározás szerint, a védelmi szektorról alkotott eddigi képzeteink képzetei - fogalmaink - is vizsgálatra szorulnak. A vizsgálat során, az egyedi esetekből való kiindulás módszertani szempont, figyelemmel William Whewell $(1989,19$. o.) tudományfilozófus megfogalmazására: „Az induktív igazság soha nem tisztán a tények összege."

A történelemben, az értelem fejlődése szerves kapcsolatban van a rendformák, intézmények, technikák, kifejezések alakulásával, változásával. A pedagógiai-antropológia aspektusából, a tudásszerveződés valószerű eredete felé mutató erőszakos, szubhumán struktúráknak jelentősége van, mint ahogyan erre hasonló vonatkozásban M. Foucault is utalt. A hadsereg sajátosan kettős alakzatú a vizsgálat szempontjából:

a) egyrészt: emberi, technikai, kibernetikai, valamint hatalmi (bürokratikus) képességek alakzata;

b) egy másik síkon: az emberi energiák felszabadításának, az ösztönök kiáramoltatásának, és elfojtásának struktúrája is.

A katonai akciók, kapcsolatok - a múködés fázisainak többségében - szükségszerűen az anyagira és a fizikaira redukálódnak. A katonai gondolkodás és az akció, igen közel kerül egymáshoz, gyakran egybekapcsolódik, és az inger-reakció modellel jellemezhető, - amint erre G. H. Mead (1973, 131. o.) utalt azzal, hogy - a parancs egyszerű kiadása szinte már magába foglalja a végrehajtást is.

A katonai nyelv szó és fogalomkészlete, valamint a katonai küzdelmi viselkedés tárgyi irányultsága, pontosan jelzi ezt az anyagit és mechanikait, így például: hadianyag, harcanyag, fegyveranyag, „emberanyag”, haderö, tömeghadsereg, gyorshadtest, ütközet, találkozóbarc, ellencsapás, stb. A világ még napjainkban is leírható a had-dal kezdődő olyan fogalomszavakkal, szimbolikus viselkedésekkel, mint: hadüzenet, hadfelszerelés, hadszintér, haditudósitás, hadirokkant, hadiárva, hadiözvegy, de az archaizmust idézik az olyan kifejezések is, mint: a diktatúra, kolónia. A „,....hadianyag az egyetlen árú,amit árra és haszonra való tekintet nélkül szórunk szét" - írta A. Huxley (1947, 49. o.). A katonai területről szétterjedt és integrálódott a taktika, stratégia, technika, logisztika intenzív, képi tartalmú nyelve.

Gondolkodásunk ellentmondása, hogy a békés polgári létet, a biztonságot fegyverrel, - végső esetben öléssel - biztosítjuk, amelynek a jogosságáról teljes bizonytalanságban vagyunk, annak ellenére, hogy Richard Rorty $(2007,27$. o.) amerikai filozófus oszlatja e bizonytalanságot a katona és rendőr tudatban, amikor kijelenti: „Ne ölj, hacsak nem országodat védő katona vagy, hacsak nem egy gyilkost akadályozol meg tettének elkövetésében, hacsak nem állami ítéletvégrehajtó vagy, hacsak nem az eutanázia irgalmas gyakorlója vagy!" Ebben a folyamatban mindig konfrontá- 
lódik a lövészárkok frontszelleme és az emberi szellem, s ez utóbbinak az érvényvesztése a legnagyobb a háborús időszakokban.

Az élethalálharc pillanataiban a világ a küzdők számára nem létezik, mint kultúra, elveszti humán információ tartalmát, ezt jelzik a szétbombázott kórházak, iskolák, templomok, temetők. Érdemes-e a katona identitásával vagy a felé vezető út - Erős Ferenc kifejezésével - fényes identitás ígéreteivel, illúzióival foglalkoznunk, amikor a tisztek is negatív identitásra voltak kényszerítve például az 1948-1989 közötti időszakban, alanyi létükért vívott küzdelmeikben sorozatos vereségeket szenvedtek.

A hadseregekben az elmúlt két évszázadban sem az ember kultusza állt a középpontban. A háború valóságos viszonyai, szélsőséges helyzetei meghatározzák, és megkeményítik a katonai vezetők karaktervonásait is, azaz, a funkció élesessége, offenzivebb karaktervonásokat eredményez: A katonai felkészítés lényege is, a katona offenziv magatartásra irányuló hajlamainak szervezése és szokásainak, karaktervonásoknak a kidolgozása, tartóssá tétele. Sokkal differenciáltabb a helyzet, mint ahogyan $\mathrm{E}$. Fromm megfogalmazta, mert lehetnek ugyan olyanok, akik a hadseregbe ,a szabadság elöl menekülnek”, ők a hivatásukat betöltő, jó végrehajtó katonák - akik nélkül a hadsereg nem működne -, azonban a rosszabb variáció az olyan karakter, amelyik a hadsereg monotóniájából menekül a háború szélsôségeibe. A katonai szervezetek olyan jellemzői, mint a „vasfegyelem”, „vak engedelmesség” a karaktert irányító mo- tívumokká válhatnak, felerősítve az előítéleteket az ettől eltérôen működő szervezetek, személyek iránt. A kemény szervezeti jellemzők teljesen hatalmukba kerithetik, megbetegithetik az én-t. Még jelenkorunkban is a nyers-katona számára egy-egy nagyváros lakói, mindig tehetetlen kispolgárok maradnak a maguk félelmeivel, szorongásaival, görcseivel, neurózisaival, divatjaival, kényeztető összkomfortosságukkal.

Négy évtizeden keresztül „résztvevőmegfigyelő" voltam a katonaéletben, és számos antropológiai párhuzamot ismertem fel. Követve az amerikai példát, nem erőszakolt beszélni az antropológia jelenlétéről a hadseregben, mert már vannak ilyen munkakörök is. Célunk, jobban megismerni és megérteni a hadsereget, a benne szolgáló katonát, a fegyveres küzdelem alanyát.

A katonai gondolkodás egyébként is, a természet, társadalom, a világ és a történelem jelenségeinek megértésén alapszik. A katonaember gondolkodása nem más, mint az emberi nem küzdelmi képességeiröl való gondolkodás, amelynek tömörített (komprimált) alakzata a háború, - a történelemben ez a harci élmények.kel, tapasztalatokkeal telítódô" tudat elsô" alakzata is - köztük a két világháború, amelyek közül az $I$. Nagy Háború végének centenáriumára emlékezett az emberiség a múlt évben.

Minden kultúra mélyén az ölés, (a gyilkolás) tragikumát találjuk, amint ezt már a klasszikus ókori görög drámaírók ábrázolták műveikben. A kulturális antropológia 
olyan elemei, mint az ellenség-barát, az eskë, a hös, a párbaj, a diadal, a temetés, a hadifogság, vagy a vallási mezőben a háborús könyörgések, stb., a maguk eredetiségében vizsgálhatók a katonai területen. Szempontunkból azonban fontosabb, hogy az indulat, a félelem, az akarat, a halál, az eröszak is e mezóbe tartozik. A vezénylő hatalom a katonát kegyetlenné, a harcbavetéssel tesżi, amikor konkréttá válike az ellenség. A test-test elleni küzdelemnek nincs más megoldása, ezért e területen egyből hasonlóvá válunk az állathoz, de az összehasonlítás e vonatkozásban sem teljesen adekvát, mert az ember bestialitásban is felülmúlja az állatot. Sqigorúan véve a háború, csak az emberi társadalmak jelensége. Az állatvilág hasonló jeleit, történéseit zavartalanul nem lehet átvinni az emberi társadalmakra - és fordítva fogalmainkkal, kategóriáinkkal adekvátan nem lehet értelmezni azokat. Egyetérthetünk M. Heideggerrel (2004, 259. o.), amikor a következőt írja: „Ha feltesszük az első kérdést: Bele tudunk-e helyezkedni az állatba? - akkor ebben tulajdonképpen mi a kérdés? Nem más, mint ez: sikerül-e az állatot követnünk azon a módon, ahogyan hall és lát, ahogyan zsákmányát megtámadja, és kitér ellenségei elöl, ahogyan fészkét építi, és effélék? Nem az a kérdéses tehát, hogy itt a létező, amibe bele akarunk helyezkedni, valami másra vonatkozik - hozzáférés a zsákmányhoz és az ellenséghez, és valahogy bánik ezekkel." A húsevô állat egyszerūen csak vadászik, az ölés járulékos eleme táplálkozásának, mivel az nem történhet meg másként, és csak történik. Vannak azonban további elgondolkodtató jelenségek a hasonlóságra, így például a találkozás aktusa, a madarak és az ember világában. Illusztrációként két vadliba csapat találkozásának leírása (Bársony, 1904, 86. o.): „Ha a nomád vonulásban két család összetalálkozik, van öröm és zajos rianás. Összefut a népség, katonaság; majd meg körülkerülgeti egymást, amíg valamelyik harcias gácsérka bele nem csíp az egyik idegenbe. Abból lesz csak a sívás, sápogás, amire következik a vizek megcsapkodása az egész sereg által. De azért csakhamar szent a béke, s vidáman válik szét a raj,..."

M. Georges Gurvitch (1963), a Szociológiai Világszövetség volt elnöke, a Sorbonne volt professzora nyomán azt mondhatjuk, hogy a csatát követő szinte azonnali békekötés jelenségének van egy, a kezdeti társadalmakra vonatkozó mozzanata, annyiban, hogy az érintettek egymást irtják, de míg az archaikus társadalmakban az erőszakot - a bizalom teljes helyreállitásaként - kötelező" párbeszéd követte, addig ma nincs ilyen törekvés. Megjegyzem, hogy különösen szembetűnő a találkozás hasonlósága, a szubkultúrájukat képviselő fiatalok csoportjainál.

\section{Módszertanilag a filozófiai-antropológia} aspektusából utalnom kell arra, hogy a tömeghadseregben minden hatás eléri az egyedi katonát is; amikor például, a hadsereg feladatává vált Magyarországon (ismételten) a belső rend fenntartása - az 1956os forradalom leverését követöen -, akkor a katona a gyakorlatban tömegoszlató ékké, karhatalmi funkcióvá vált. A pszichológi- 
ai, szociológiai, kommunikációs, kulturális-antropológiai kutatásokat is a hadviselés szükséglete - az ellenség pontosabb megismerésére való törekvés - ösztönözte. A kezdeti időszakban változó tudományossággal folytak a gyakorlati kísérletek (ismertek a haláltáborokba deportáltakon végzett embertelen kísérletek), és a gondolatkísérletek; vagy a veszélyérzet által motivált kutatásokra »vörös rém« természetének megismerésére, az 1950-es években Amerikában, ami azonban bizonyára még napjainkban is foglalkoztatja a kutatók és stratégák egy részét. Ezek a politikai-propagandában fel-felbukkanó srémek" kifogyhatatlanok, mondhatjuk az elmúlt évtizedek tapasztalatai alapján még itt Európában is.

Az ember megítélése kiszakíthatatlan történetiségéből. Az emberi viselkedés „természetessége” a kultúra, a társadalmiság hatására sokat veszített eredeti jellemzőiből (kényelmes életfeltételek, a munka gépesítettsége, automatizálása inkább az intellektuális készségeket fejleszti, fizikailag inkább elpuhít, stb.). Úgy vélem, hogy a történelem az ember nembeli lényegének, képességeinek kidolgozási folyamata. A történetikronológia bizonyos értelemben veszít jelentőségéből, mert a tartamok folyamatossága fragmentumokban, szellemi késztetésekben, valamint más alakzatokban mindig jelen van, és összehasonlíthatók egymással az eltérő korszakokban is. A háború az emberi élethez ismétlődően hozzátartozó jellemző, azaz eredeti alakzatában ősi örökség, amit nemcsak a történelemtudományon belül lehet megköze- líteni. A hadsereg genézise az ember szempontjából minden olyan tartamot magába foglal, amely lényegét tekintve nem változott. A háború elméletek egyre árnyaltabbá váltak, de a technika-technológia hatására, a háború gyakorlata egyre barbárabb. Nem a tartam minemúsége, hanem, a funkcionálás hogyanja változott a történelemben. Két alapvető jellemzőt említhetünk a változókekal kapcsolatban:

1) a harci tapasztalatok halmozódását, amelyek visszahatnak a harcmódra; valamint

2) a haditechnika, a harcanyagok cserélődését, helyettesítődését a tudományok és a technika fejlődésének eredményeként.

Ha a szerző és az időpont ismerete nélkül olvasnánk például, a háborúra való készenlét vagy a háborúk felosztását, akár korunkban is érvényesnek tarthatnák Richelieu osztályozását a háborúkról (Richelieu, 1688/1985 művére hivatkozik: Hildesheimer és Harai, 2015): az állam felgyülemlett rossz energiáinak kiadása; visszaszerezni, amit elvettek; megbosszulni a sérelmeket, amelyeknek büntetlenül hagyása újabb sérelmekhez vezet; a szövetségesek megvédése mások intervenciójától; a hódító gőgjének letörése; veszélyek megelőzése, valamint különbözọ más okok miatt.

Meg kell jegyeznem azonban, hogy minél mesterségesebb egy társadalom, annál mesterkéltebbek szükségletei, érdekei, értékei, céljai, szabályai, stratégiái, és képzetei, annál torzabb foncsorozottságú az a tükör, amelyben látja önmagát. 
Módszertanilag hangsúlyozni kell azt az eltérést, ami a hadseregek és a műszaki/ technikai tudomány, valamint a társadalomtudomány között van. A társadalomtudomány átrendezi, variálja a szabályszerűségek, fogalmak, események közötti folyamatokat, amelyek például a hadtudomány és a politikatudomány esetében, bizonyos időszakokban deduktív módon egybekapcsolódtak (gondoljunk a sztáliniidőszakra). Ezért a módszer kritikai. E módszerrel azt a bevett, több tekintetben vak, konszenzust is kívánom oldani, ami a hadtudományi munkák olvasói között húzódik, és kevésbé tolerálja az eltérést ettől a reflextől. A mostani időszak azonban már olyan, hogy újra kell értelmeznünk a civil társadalom és a hadsereg, valamint a katona viszonyát a hadsereghez s önmagához. H. Barbusse kifejezésével a társadalomtudomány geometriává, érzelemmentes szabályrendszerré vált a 20. század háborús, totális időszakaiban. Ezt a ridegséget a pszichoanalizis törte át a múlt század elején. A pszichoanalízis keletkezésétől fogva érzékeny, kritikus viszonyban van a totalitárius hatalommal, és a háborúval. A maximát, amit Szun-ce megfogalmazott, hogy ,,ismerd az ellenséget és ismerd önmagadat s legyőzhetetlen leszel", végsősoron a pszichoanalízis segítségével lehet kiaknázni, a harc szélsőséges fázisaiban az emberi viselkedéseket megérteni. A valóban tudományos logika - vélekedett Ferenczi Sándor - szándékosan nem hagyhat feltáratlanul, valami valóságosan létező dolgot. Vissza kell térnünk produktív jelzéseihez, magyarázó elveihez, tárgyá- hoz, ha a katona antropológiai, filozófiaiantropológiai jellemzőiről gondolkodunk. Jelenkorunk eseményei nyomán azt tapasztaljuk, hogy emberi stádiumba többször juthat az ember, de többször is kieshet belőle.

A tudományos humanizmus szempontjából közelítve sem kerülheti el figyelmünket történetileg, hogy a hadi mesterségben való jártasság nélkül, nem lehetett volna államot alapitani és megvédeni. A küzdőképességnek ez a formája nem veszített értékéből. Az elmúlt évszázadokban a harc a zoológia törvényére redukálódott. A történelem az erók leltára. A világháborúk a pusztítás nagyipari eszközeit, a destruktív ösztönökkel összekapcsolva, az egész civilizációs héjszerkezetet lerobbantották az emberiségről. A történelem kódolta bennünk, hogy a háborút csak halálként és szenvedésként értjük. A harcoló katona is J. Huizinga (1991, 82. o.) megfogalmazásában - „Kimondhatatlanul többet szenved, mint amennyit cselekszik, s cselekvése is szenvedés." A katona egyébként, a totális rendszerekben nem a halála pillanatában válik áldozattá, hanem folyamatosan ą: Nem véletlen, hogy már gyermekkorban kifejlődik bizonyos tartózkodás, a katonai szolgálattal szemben. A hetvenes évek végén az egyik honvédelmi napon, amely az általános iskolás gyerekeknek volt hívatott bemutatni a hadsereget, megkérdeztem a körülöttem álló 6-8 gyereket, hogy ki nem akar katona lenni? Egy gyerek jelentkezett. Kérdésemre, hogy „Mit csinál, ha mégis be kell majd vonulnia?” azt válaszolta - a többiek érdeklődé- 
sétôl kísérve - „Beteg leszek, felmegyek a gyengélkedőre, onnan kiküldenek a kórházba, a kórházból leszerelek és visszamegyek civilbe." A körülbelül harmadikos (8 éves) gyerek válasza mutatja, hogy eddig az életkorig ismert volt a betegségen/lelki betegségen keresztül vezető út a szolgálattól való megszabaduláshoz, vagy, ami akkor igen fenyegetően hangzott, mint büntetési tétel - a szolgálat alóli kibúváshoz. A valóban betegeknek azonban, a hadsereg sohasem pszichológiai rejtvény, sokkal inkább csapda, amelyben vergődnek. A pedagógiai cél úgy gondolom, az optimális fejlődés lehet (lásd Zrinszky, 2002 nevelés fogalmát) napjainkban, amely igazodik az életkori sajátosságokhoz, fenyegetésektől, destrukcióktól mentes, alanyi részvételen alapuló.

Összességében, e munka célja rendezni, értelmezni valamint magyarázni a jelenségeket és tényeket, megállapítva bizonyos szabályszerűségeket, vázolva a katona antropológiájának tartalmi vonatkozásait. Jean-Francois Lyotard kifejezésével az intellektuális divatok váltakozása a maguk intézményeivel az elmúlt néhány évtizedben mintha felgyorsult volna, és gyakran átcsapnak szellemi korrupcióba is. Ezek a divatok gyakran ráközelítenek a társadalom berendezkedésének problematikájára, és vádolják egymás felemásra sikerült alakzatait, amelyek már nem csak ,beszédmódok", hanem az emberi gondolkodást megnyomorító realitások is. Gon- doljuk végig Magyarország esetében a 20. század nyolc-kilenc rendszerváltását. A téma nemcsak érinti, hanem fontos részét képezi a hatalmi struktúrák és hatalmi viszonyok, önmagukon belüli szerveződése, szabályrendszere, valamint hatása van a kultúrára és az emberekre. Ma tudjuk, hogy nem csak parlamentáris demokrácia van, hanem van közvetlen, elnöki, direktóriumi, sőt parancsuralmi demokrácia is, feltéve, hogy az államakaratot és a népet összekötő kapocs megvan, és aki a hatalmat gyakorolja, bárki is az, számadással tartozik az ellenőrző népnek és elmozdítható - írta Wilhelm Röpke. Természetesen közben lehetnek aggasztó határesetek, ez utóbbi megjegyzésébe belefér a katonai demokrácia is. Majd hozzáteszi: minden korszakot az jellemez legjobban, mi a véleménye Caesarról, Nagy Sándorról, Cromwellről, Richelieuről vagy Napóleonról. Egy személyes beszélgetés alkalmával mondta nekem Kéry Kálmán vezérezredes, hogy gyakran lebecsülik a katonai rendszerekben a demokratikus elemek jelentőségét. A „katonai-demokrácia” szóösszetétel ettől függetlenül okozhat némi zavart. Felvethetjük, hogy lehet-e mérőeszköz az, hogyan vélekednek a megkérdezettek ezekről az „erőszak-emberek”ről. A vonatkozási pontként megjelölt, kiemelkedő történelmi személyiségek is mind eltérő rendszereket működtettek.

Van néhány faktor, amelyek mindig valamilyen rezonancia szinten jelen vannak a társadalmak életében, így:

a) az erôszak valamelyik típusa (ez nem tisztán megállapodás vagy raciona- 
lizmus kérdése, mert ha csak az lenne, már megteremthetô lett volna a kultúrák demilitarizálása). Más azonban a szervezett és a szerves erőszak. Kultúrákat azonban csak olyanokat ismerünk a történelemben, amelyekben hadseregek is voltak.

b) Az integráció és a dezintegráció, amelynek járuléka lehet egyes embereknél és csoportoknál a társadalomból való „kiesés” (másként a: deséncadrement).

c) az autonomia (saját akarat) valamint a heteronómia (idegen akarat) is mindig rezonál.

A királyság, kereszténység, katonaság komoly hagyománya a társadalmaknak, amely fölött szemet hunyni lehet ugyan, de teljesen megkerülni nem. A téma lényege, egy-egy társadalom hatékony vezérlésének kérdése. Egyetlen társadalmi alakzat (rendszer) sem állandó a történelemben. Vannak a történelemnek szerves összefüggései, gondoljunk például az ipari korszakra, amely egyben a tömegek, a világválságok, a világháborúk korszaka is. $\mathrm{E}$ felsorolással jelezhetjük ennek a szerves folyamatnak az olyan következményeit, mint a környezetpusztítás, a tömeges elnyomorodás, és nem utolsó sorban a katonai demokráciák.

G. F. Kennan (1904-2005) történész, volt diplomata, „A történelem eleven valósága, George F. Kennan és John Lukacs levelezése" - címú munkájukban megfogalmazza, hogy (Kennan 1966. június 17-i leveléből idézi: Lukacs, 2010, 50-
51. o.): „,...a történelem megkülönböztető vonása az a tény, hogy elsődlegesen az egyénnel kell foglalkoznia, annak minden különösségét figyelembe véve. Csakhogy nincs teljesen objektív platform, melyről az egyén megítélhető volna. Az ítélet - és ez a szépsége és a gazdagsága - mindig két egyén, a megítélt és a megítélő összjátékának eredménye, és ugyanannyira tükrözi és jellemzi az utóbbit, mint az előbbit. Egy másik egyén személyiségének elemzése és viselkedésének leírása nem választható el teljesen saját személyiségünktől és viselkedésünktől: e dolog megértése bizonyos fokig egyet jelent önmagunk megértésével és ennél fogva önmagunk fölé emelkedéssel. Más szóval a történelmi megismerés részben az önmegismerés egy formája."

\section{Irodalom}

Bálint L. (szerk.)(1924): Nagy Írók - Nagy Írások. Harmadik Sorozat I.: Balassa Bálint Minden Munkái. Genius, Budapest.

Bársony István (1904): Erdön mezoón - Természeti és vadászati képek. Athenaeum Irodalmi és Nyomdai Részv.Társ. Kiadása, Budapest.

Borzsák I. (1984): A Nagy Sándor - hagyomány Magyarországon. Akadémia Kiadó, Budapest.

Campanella, T. (1602/1942): Napállam. Phönix, Budapest.

Eco, U. (2007): Gyufalevelek. Európa Könyvkiadó, Budapest.

Fehér F. (2007): A bestiárium antropológiája (Politikai filozófiai tanulmányok). 
GOND-CURA Alapítvány, Budapest. 9. o.

Ferenczi S. (1918): A mechanika lelki fejlődéstörténete (Kritikai megjegyzések Ernst Mach egy tanulmányához). Nyugat (11) 1918, II, 13-24. szám $487-$ 494. o.

Gurvitch, M. G. (1963): Déterminismes sociaux et liberté humaine: vers l'étude sociologique des cheminements de la liberté. Paris: PUF

Hahn I. (szerk.) (963): A hadmüvészet ókori klasszikusai. Zrínyi Katonai Kiadó, Budapest. 223 -224. o.

Heidegger, M. (2004): A metafizika alapfogalmai. Osiris Kiadó, Budapest

Hildesheimer, F. \& Harai, D. (2015): Dictionnaire Richelieu. Paris: Honoré Champio

Huizinga, J. (1991): A bolnap árnyékában Korunk kulturális bajainak diagnórisa. Tevan kiadó, Békéscsaba

Huxley, A. (1947): Tudomány, szabadság, béke. Franklin Társulat, Budapest.

Lukacs, J. (szerk.)(2010): A történelem eleven valósága - George F. Kennan és John Lukacs levelezése. Európa Kiadó, Budapest

Macaulay, T. B. (1961): Esszék. In: Sükösd M. (szerk.): Macaulay esszék. Gondolat Kiadó, Budapest.
Malinowski, B. (1968): Une Théorie scientifique de la culture et autres essais. $\mathrm{Pa}$ ris: François Maspero.

Mead, G. H. (1973): A psqichikum, az én és a társadalom - sqociálbehaviorista szempontból. Gondolat Kiadó, Budapest.

Morgan, L. H. (1962): Az ôsi társadalom. Gondolat Kiadó, Budapest.

Nagel, E. (2005): Funkcionalizmus a társadalomtudományban. In Bertalan L. (szerk.): A társadalomtudományi fogalmak logikája. Klasszikus tudományfilozófiai írások. Helikon Kiadó, Budapest. 201. o.

Richelieu, A. J. du P. (1688/1985): Testament politique d'Armand du Plessis, cardinal duc de Richelieu. Caen: Centre de philosophie politique et juridique

Ricoeur, P. (1991): A bizonyítás problémája Freud pszichoanalitikai műveiben. Thalassa, 1991 (2), 93- 114. o.

Rorty, R. (2007): Filozófia és társadalmi remény. L'Harmattan Kiadó - Magyar Filozófiai Társaság, Budapest.

Schopenhauer, A. (1943): Szerelem, élet, halál. Franklin Társulat, Budpest.

Whewell, W. (1989): Theory of Scientific Method. Cambridge: Hackett Publishing Company.

Zrinszky L. (2002): Neveléselmélet. Műszaki Könyvkiadó, Budapest 